2018-01-0191

\title{
Reduced gasoline surrogate (toluene/n-heptane/iso-octane) chemical kinetic model for compression ignition simulations
}

Author, co-author (Do NOT enter this information. It will be pulled from participant tab in MyTechZone) Affiliation (Do NOT enter this information. It will be pulled from participant tab in MyTechZone

\begin{abstract}
Toluene primary reference fuel (TPRF) (mixture of toluene, iso-octane and heptane) is a suitable surrogate to represent a wide spectrum of real fuels with varying octane sensitivity. Investigating different surrogates in engine simulations is a prerequisite to identify the best matching mixture. However, running 3D engine simulations using detailed models is currently impossible and reduction of detailed models is essential. This work presents an AramcoMech reduced kinetic model developed at King Abdullah University of Science and Technology (KAUST) for simulating complex TPRF surrogate blends. A semi-decoupling approach was used together with species and reaction lumping to obtain a reduced kinetic model. The model was widely validated against experimental data including shock tube ignition delay times and premixed laminar flame speeds. Finally, the model was utilized to simulate the combustion of a low reactivity gasoline fuel under partially premixed combustion conditions.
\end{abstract}

\section{Introduction}

The need for cleaner and more efficient combustion technologies has motivated research in advanced engine concepts [1,2]. Numerical simulations utilizing detailed and/or skeletal chemical kinetic models have become common tools for the design and development of novel engine technologies. Of principal importance is understanding fuel/engine interactions [3] when burning complex hydrocarbon fuel mixtures derived from petroleum. Modeling of chemical reactions occurring during combustion of such complex fuel mixtures (e.g., gasoline and diesel) is typically achieved using surrogate fuels [4-6] mixtures that emulate properties of the target fuel.

The most commonly used gasoline surrogates include primary reference fuel (PRF) mixtures of n-heptane and iso-octane and toluene PRF (TPRF) mixtures comprising toluene, $\mathrm{n}$-heptane, and iso-octane. There are numerous chemical kinetic models in the literature for such mixtures. However, most of these are based on older detailed kinetic models for $\mathrm{C}_{0}-\mathrm{C}_{4}$ chemistry and n-heptane, iso-octane, and toluene [7-13]. This work provides a skeletal kinetic model for TPRF mixtures that is based on newly developed and widely validated kinetic models for $\mathrm{C}_{0}-\mathrm{C}_{4} \mathrm{species}\left(\mathrm{AramcoMech}_{\mathrm{B}}\right.$ [14-16] n-heptane [17], iso-octane [18], and toluene [19,20]. In addition, the model is validated against recently published ignition delay data for PRF [21] and TPRF [22] mixtures. Furthermore, the present model is utilized for multi-dimensional compression ignition engine simulations.

Table 1 - Skeletal chemical kinetic models for PRF and TPRF surrogates fuels

\begin{tabular}{|c|c|c|}
\hline Fuel components & Authors/Reference & $\begin{array}{l}\text { \# of Species / \# of } \\
\text { Reactions }\end{array}$ \\
\hline $\begin{array}{l}\text { n-heptane/iso-octane } \\
\text { (PRF) }\end{array}$ & $\begin{array}{l}\text { Tanaka et al., } 2003 \\
{[23]}\end{array}$ & $\begin{array}{l}32 \text { species / } 55 \\
\text { reactions }\end{array}$ \\
\hline $\begin{array}{l}\text { n-heptane/iso-octane } \\
\text { (PRF) }\end{array}$ & $\begin{array}{l}\text { Chaos et al., } 2007 \\
\text { [24] }\end{array}$ & $\begin{array}{l}107 \text { species / } 723 \\
\text { reactions }\end{array}$ \\
\hline $\begin{array}{l}\text { n-heptane/iso-octane } \\
\text { (PRF) }\end{array}$ & $\begin{array}{l}\text { Wang et al., } 2013 \\
{[25]}\end{array}$ & $\begin{array}{l}73 \text { species / } 296 \\
\text { reactions }\end{array}$ \\
\hline $\begin{array}{l}\text { n-heptane/iso-octane } \\
\text { (PRF) }\end{array}$ & $\begin{array}{l}\text { Luong et al., } 2013 \\
\text { [26] }\end{array}$ & 116 species \\
\hline $\begin{array}{l}\text { n-heptane/iso-octane } \\
\text { (PRF) }\end{array}$ & $\begin{array}{l}\text { Ra and Reitz, } 2008 \\
{[27]}\end{array}$ & $\begin{array}{l}41 \text { species / } 130 \\
\text { reactions }\end{array}$ \\
\hline $\begin{array}{l}\text { n-heptane/iso-octane } \\
\text { (PRF) }\end{array}$ & $\begin{array}{l}\text { Zhen et al., } 2016 \\
{[28]}\end{array}$ & $\begin{array}{l}51 \text { species / } 193 \\
\text { reactions }\end{array}$ \\
\hline
\end{tabular}

n-heptane/iso-octane

(PRF)

n-heptane/iso-octane

(PRF)

Page 1 of 16

\footnotetext{
Wang et al., 201622 species / 21

[29] reactions

Zhou et al., 201646 species / 144

[30] reactions
} 


\begin{tabular}{|c|c|c|c|}
\hline $\begin{array}{l}\text { n-heptane/iso-octane } \\
\text { (PRF) }\end{array}$ & Liu et al., 2012 [31] & $\begin{array}{l}41 \text { species } \\
\text { reactions }\end{array}$ & / 124 \\
\hline $\begin{array}{l}\text { n-heptane/iso- } \\
\text { octane/toluene } \\
\text { (TPRF) }\end{array}$ & $\begin{array}{l}\text { Machrafi et al., } \\
2008 / 2009 \text { [32-34] }\end{array}$ & $\begin{array}{l}49 \text { species } \\
\text { reactions }\end{array}$ & / 62 \\
\hline $\begin{array}{l}\text { n-heptane/iso- } \\
\text { octane/toluene } \\
\text { (TPRF) }\end{array}$ & Kim et al., 2007 [35] & $\begin{array}{l}44 \text { species } \\
\text { reactions }\end{array}$ & / 59 \\
\hline $\begin{array}{l}\text { n-heptane/iso- } \\
\text { octane/toluene } \\
\text { (TPRF) }\end{array}$ & Kim et al., 2010 [36] & $\begin{array}{l}48 \text { species } \\
\text { reactions }\end{array}$ & / 67 \\
\hline $\begin{array}{l}\text { n-heptane/iso- } \\
\text { octane/toluene } \\
\text { (TPRF) }\end{array}$ & Raj et al., 2011 [37] & $\begin{array}{l}226 \text { species } \\
\text { reaction }\end{array}$ & / 2121 \\
\hline $\begin{array}{l}\text { n-heptane/iso- } \\
\text { octane/toluene } \\
\text { (TPRF) }\end{array}$ & Liu et al., 2013 [38] & $\begin{array}{l}56 \text { species } \\
\text { reactions }\end{array}$ & / 168 \\
\hline $\begin{array}{l}\text { n-heptane/iso- } \\
\text { octane/toluene } \\
\text { (TPRF) }\end{array}$ & $\begin{array}{l}\text { Andrae et al., } 2013 \\
{[9,39,40]}\end{array}$ & $\begin{array}{l}137 \text { species } \\
\text { reactions }\end{array}$ & / 635 \\
\hline $\begin{array}{l}\text { n-heptane/iso- } \\
\text { octane/toluene } \\
\text { (TPRF) }\end{array}$ & $\begin{array}{l}\text { Wang et al., } 2015 \\
\text { [41] }\end{array}$ & $\begin{array}{l}109 \text { species } \\
\text { reactions }\end{array}$ & / 543 \\
\hline $\begin{array}{l}\text { n-heptane/iso- } \\
\text { octane/toluene } \\
\text { (TPRF) }\end{array}$ & $\begin{array}{l}\text { Zheng and Lv, } 2015 \\
\text { [42] }\end{array}$ & $\begin{array}{l}80 \text { species } \\
\text { reactions }\end{array}$ & / 184 \\
\hline $\begin{array}{l}\text { n-heptane/iso- } \\
\text { octane/toluene } \\
\text { (TPRF) }\end{array}$ & $\begin{array}{l}\text { Stagni et al., } 2016 \\
{[43]}\end{array}$ & $\begin{array}{l}115 \text { species } \\
\text { reactions }\end{array}$ & / 856 \\
\hline $\begin{array}{l}\text { n-heptane/iso- } \\
\text { octane/toluene } \\
\text { (TPRF) }\end{array}$ & An et al., 2015 [44] & $\begin{array}{l}219 \text { species } \\
\text { reactions }\end{array}$ & / 1229 \\
\hline $\begin{array}{l}\text { n-heptane/iso- } \\
\text { octane/toluene } \\
\text { (TPRF) }\end{array}$ & An et al., 2016 [45] & $\begin{array}{l}85 \text { species } \\
\text { reactions }\end{array}$ & / 232 \\
\hline
\end{tabular}

Many compression ignition engine technologies have been investigated because of their ability to combine the best of gasoline and diesel engines. Combustion strategies such as homogeneous charge compression ignition (HCCI) [46], reactivity-controlled compression ignition (RCCI) [47,48], and partially-premixed compression ignition (PPCI) [49,50] bring together the benefits of the relatively simple design of gasoline engines and their after treatment systems and the higher efficiencies of diesel engines. These engine concepts have some high-level characteristics in common even though the engine operating parameters such as timing and number of injections, fuel type, and air system requirements may differ. PPCI engines, in particular, can be operated at a wide range of conditions such as load and speed.

The specifications of the enabling fuels for the PPCI engine technology are not very well defined until now. Many fuels with varying physical and chemical properties, such as ignition quality, distillation curve and chemical compositions, have been considered in previous works. These include conventional gasoline, conventional diesel, gasoline-diesel blends ("dieseline"), low-octane gasolines ("naphthas") and reference fuel blends (composed of iso-octane, n-heptane, toluene) [51]. Certain fuel properties affect the performance of the engine because PPCI combustion is dependent on mixture stratification as well as chemical kinetics. For example, some studies show that the soot emissions of PPCI engines are impacted by the fuel distillation and aromatic content [52,53], while others report a minimal effect [54]. Nonetheless, all the studies have shown that fuel reactivity, or homogeneous ignition delay, is an important factor in optimizing the performance of PPCI engines over wide range of operating conditions. The utilization of computational fluid dynamics (CFD) to optimize engines requires the use of simpler surrogate mixtures which mimic the characteristics of real fuel. The surrogates for gasoline-like fuels range from simple binary or ternary mixtures of iso-octane, n-heptane and Page 2 of 16 
toluene to more complex mixtures containing additional species such as n-butane, iso-pentane, cyclo-pentane, 1-hexene, 1-pentene, 1,2,4trimethylbenzene, and others. Many studies are available in literature on surrogate formulation strategies to match the physical and chemical properties of real fuels but most previous work was focused on gasoline and diesel [5,55-62] Recently, there has been some focus on formulating surrogates for low-octane gasoline and naphtha fuels [63].

Refinery streams such as petroleum naphtha with research octane numbers (RON) in the 50 - 80 range have recently been considered attractive alternatives to provide suitable chemical characteristics (longer ignition delay than diesel) in compression ignition engines. These naphtha fuels can be produced in the refinery at lower cost and result in decreased well-to-tank $\mathrm{CO}_{2}$ emissions. Hao et al. [64] found that compared with the conventional pathway, the low-octane fuel pathway leads to a $24.6 \%$ reduction in energy consumption and a $22.8 \%$ reduction in GHG emissions.

\section{Experimental and Numerical methodology}

\subsection{Reduction of Base Chemistry}

A decoupling methodology $[38,65,66]$ was employed to develop a new skeletal mechanism for PRF fuel mixtures. The first stage in the decoupling method involves a detailed description of $\mathrm{H} 2 / \mathrm{CO} / \mathrm{C} 1$ chemistry and the reduction of $\mathrm{C} 2 / \mathrm{C} 3$ sub-model using Direct Relation Graph with expert knowledge (DRG-X) [67,68]. As has been reported in our previous studies, DRG-X method is based on the assumption that during combustion processes, some species are weakly connected to others and barely contribute to the reaction process. Those loosely coupled species can be removed from the mechanism and still retain the chemical fidelity of the detailed model [69]. A global error tolerance can be specified to eliminate species whose removal does not significantly affect the reaction rates of major species, as determined by the pair-wise error [67,68]. Furthermore, the DRG$\mathrm{X}$ method is not limited to an overall error tolerance, as it allows a specific controlled reduction error for heat release and other species of interest. Species specific error tolerances permit the user to obtain smaller chemical kinetic mechanisms by eliminating the need to set a very low global error tolerance. In the present work, the AramcoMech 2.0 [14-16,70,71] detailed model was reduced across a wide range of suitable engine conditions (high pressure and low to high temperatures and lean-rich equivalence ratios). Propene was specified as the fuel with an error tolerance for heat release set at 0.3 . The error tolerance for $\mathrm{H}$ and $\mathrm{CH} 3$ and $\mathrm{HCO}$ radicals is 0.5 , while the default global error tolerance for other species is 0.4 .

\section{2 n-Heptane and iso-octane sub-models}

$n$-Heptane and iso-octane oxidation sub-mechanisms are developed based on Tanaka [23] and Tsurushima [72] recommendations, where only one species is considered for each reaction class . A simplified scheme for the development of lumped heptane and iso-octane sub-mechanisms is illustrated in reactions 1-9 below. Reactions are initiated by fuel abstraction by $\mathrm{O}_{2}$. At high temperature, fuel abstractions by $\mathrm{OH}$ and $\mathrm{HO}_{2}$ along with beta scission reactions take place. The low temperature chemistry includes radical addition to molecular oxygen, $\mathrm{RO}_{2}$ isomerization, second $\mathrm{O}_{2}$ addition and the formation of ketohydroperoxide $+\mathrm{OH}$. Concerted elimination $\left(\mathrm{RO}_{2}=\right.$ olefin $\left.+\mathrm{HO}_{2}\right)$ is added to compete with the addition to $\mathrm{O}_{2}$ and consequently control or decrease reactivity at low temperatures. The formed KHP decomposes to aldehydes, then formed aldehydes and olefins decompose via the reaction with $\mathrm{O}_{2}$ to form smaller species exist in the base chemistry.

$\begin{array}{ll}\mathrm{RH}+\left(\mathrm{O}_{2} / \mathrm{OH} / \mathrm{H}_{2} \mathrm{O}\right)=\mathrm{R}+\left(\mathrm{HO}_{2} / \mathrm{H}_{2} \mathrm{O} / \mathrm{H}_{2} \mathrm{O}_{2}\right) & 1,2,3 \\ \mathrm{R}+\mathrm{O}_{2}=\mathrm{RO}_{2} & 4 \\ \mathrm{RO}_{2}=\text { olefin }+\mathrm{HO}_{2} & 5 \\ \mathrm{RO}_{2}=\mathrm{QOOH} & 6 \\ \mathrm{QOOH}=\mathrm{O}_{2}=\mathrm{O}_{2} \mathrm{QOO} & 7 \\ \mathrm{O}_{2} \mathrm{QOOH}=>\mathrm{KHP}+\mathrm{OH} & 8 \\ \mathrm{KHP}=>\mathrm{RCO}+\mathrm{CH}_{2} \mathrm{O}+\mathrm{OH} & 9\end{array}$

The lumped sub-models for $n$-heptane and iso-octane are based on the recent detailed models by Zhang et al. [17] and Atef et al. [18], respectively. First, preliminary rate parameters were assigned based on the total rate constants $(\mathrm{k})$ of all reactions included within a single class across a temperature range from 600 to $1500 \mathrm{~K}$ in the detailed model. To elucidate the dependency of rates on thermodynamic properties, the reversible rates of all reaction were assigned using the same approach. Next, simulations were conducted and the results were compared against the experimental data. Finally, rate parameters were optimized accordingly to match the experimental data. The reactivity at different pressures was controlled by adopting pressure dependent rate rules for $\mathrm{C} 8 \mathrm{H} 17 \mathrm{O} 2<=>\mathrm{C} 8 \mathrm{H} 16+\mathrm{HO}_{2}$, which is applicable for such a unimolecular reaction. Table 1 shows the rate parameters of all the reactions in the iso-octane and $n$-heptane sub-models.

Table 2 - n-Heptane and iso-octane sub-mechanisms

\begin{tabular}{lccc}
\hline Reactions & A & Ea & \\
\hline
\end{tabular}

Heptane sub-mechanism

Page 3 of 16 


\begin{tabular}{|c|c|c|c|}
\hline $\mathrm{NC} 7 \mathrm{H} 16+\mathrm{O}_{2}<=>\mathrm{NC} 7 \mathrm{H} 15+\mathrm{HO}_{2}$ & $9.00 \mathrm{E}+13$ & 0 & 50424.1 \\
\hline Reverse Arrhenius coefficient & $6.00 \mathrm{E}+11$ & 0 & 1172.5 \\
\hline $\mathrm{NC} 7 \mathrm{H} 16+\mathrm{OH}=>\mathrm{NC} 7 \mathrm{H} 15+\mathrm{H}_{2} \mathrm{O}$ & $1.00 \mathrm{E}+14$ & 0 & 2907.0 \\
\hline $\mathrm{NC} 7 \mathrm{H} 16+\mathrm{HO}_{2}=>\mathrm{NC} 7 \mathrm{H} 15+\mathrm{H}_{2} \mathrm{O}_{2}$ & $6.00 \mathrm{E}+12$ & 0 & 19534.2 \\
\hline $\mathrm{NC} 7 \mathrm{H} 15=>\mathrm{C}_{3} \mathrm{H} 6+\mathrm{C}_{2} \mathrm{H}_{5}+\mathrm{C}_{2} \mathrm{H}_{4}$ & $1.20 \mathrm{E}+11$ & 0 & 28728.0 \\
\hline $\mathrm{NC} 7 \mathrm{H} 15+\mathrm{O}_{2}<=>\mathrm{NC} 7 \mathrm{H} 15 \mathrm{OO}$ & $9.00 \mathrm{E}+12$ & 0 & 0.0 \\
\hline Reverse Arrhenius coefficient & $1.25 \mathrm{E}+15$ & 0 & 33510.8 \\
\hline $\mathrm{NC} 7 \mathrm{H} 15 \mathrm{OO}<=>\mathrm{NC} 7 \mathrm{H} 14 \mathrm{OOH}$ & $1.20 \mathrm{E}+11$ & 0 & 21350.3 \\
\hline $\mathrm{NC} 7 \mathrm{H} 15 \mathrm{OO}=\mathrm{NC} 7 \mathrm{H} 14+\mathrm{HO}_{2}$ & $5.40 \mathrm{E}+12$ & 0 & 28000.0 \\
\hline $\mathrm{NC} 7 \mathrm{H} 14 \mathrm{OOH}+\mathrm{O}_{2}=\mathrm{OONC} 7 \mathrm{H} 14 \mathrm{OOH}$ & $1.00 \mathrm{E}+12$ & 0 & 0.0 \\
\hline Reverse Arrhenius coefficient & $4.44 \mathrm{E}+10$ & 0 & 22957.8 \\
\hline $\mathrm{OONC} 7 \mathrm{H} 14 \mathrm{OOH}=>\mathrm{NC} 7 \mathrm{KET}+\mathrm{OH}$ & $2.00 \mathrm{E}+11$ & 0 & 18346.0 \\
\hline $\mathrm{NC} 7 \mathrm{KET}=>\mathrm{OH}+\mathrm{CH}_{2} \mathrm{O}+\mathrm{NC} 5 \mathrm{H} 11 \mathrm{CO}$ & $4.00 \mathrm{E}+15$ & 0 & 39000.0 \\
\hline $\mathrm{NC} 5 \mathrm{H} 11 \mathrm{CO}+\mathrm{O}_{2}=>\mathrm{IC} 3 \mathrm{H} 7+\mathrm{C} 2 \mathrm{H} 3+\mathrm{CO}+\mathrm{HO} 2$ & $3.16 \mathrm{E}+13$ & 0 & 10000.0 \\
\hline $\mathrm{NC} 7 \mathrm{H} 14+\mathrm{O}_{2}=>\mathrm{C}_{3} \mathrm{H}_{6}+\mathrm{C}_{2} \mathrm{H}_{5}+\mathrm{CH}_{2} \mathrm{O}+\mathrm{HCO}$ & $3.16 \mathrm{E}+13$ & 0 & 10000.0 \\
\hline \multicolumn{4}{|c|}{ iso-octane sub-mechanism } \\
\hline $\mathrm{IC} 8 \mathrm{H} 18+\mathrm{O}_{2}<=>\mathrm{C} 8 \mathrm{H} 17+\mathrm{HO}_{2}$ & $1.00 \mathrm{E}+14$ & 0 & 50271.0 \\
\hline Reverse Arrhenius coefficient & $2.00 \mathrm{E}+12$ & 0 & 1475.0 \\
\hline $\mathrm{IC} 8 \mathrm{H} 18+\mathrm{OH}<=>\mathrm{C} 8 \mathrm{H} 17+\mathrm{H}_{2} \mathrm{O}$ & $1.63 \mathrm{E}+07$ & 2.03 & 0.0 \\
\hline Reverse Arrhenius coefficient & $5.00 \mathrm{E}+15$ & 0 & 25650.0 \\
\hline $\mathrm{IC} 8 \mathrm{H} 18+\mathrm{HO}_{2}<=>\mathrm{C} 8 \mathrm{H} 17+\mathrm{H}_{2} \mathrm{O}_{2}$ & $3.00 \mathrm{E}+13$ & 0 & 18740.0 \\
\hline Reverse Arrhenius coefficient & $5.00 \mathrm{E}+12$ & 0 & 10400.0 \\
\hline $\mathrm{C} 8 \mathrm{H} 17=>\mathrm{IC}_{3} \mathrm{H}_{7}+\mathrm{C}_{3} \mathrm{H}_{6}+\mathrm{C}_{2} \mathrm{H}_{4}$ & $1.00 \mathrm{E}+18$ & -1.27 & 29700.0 \\
\hline $\mathrm{C} 8 \mathrm{H} 17+\mathrm{O}_{2}<=>\mathrm{C} 8 \mathrm{H} 17 \mathrm{O} 2$ & $2.50 \mathrm{E}+12$ & 0 & 465.0 \\
\hline Reverse Arrhenius coefficient & $2.50 \mathrm{E}+15$ & 0 & 31300.0 \\
\hline $\mathrm{C} 8 \mathrm{H} 17 \mathrm{O} 2<=>\mathrm{C} 8 \mathrm{H} 16 \mathrm{OOH}$ & $2.86 \mathrm{E}+11$ & 1.23 & 22000.0 \\
\hline $\mathrm{C} 8 \mathrm{H} 17 \mathrm{O} 2<=>\mathrm{C} 8 \mathrm{H} 16+\mathrm{HO}_{2}$ & $8.0 \mathrm{E}+14$ & 0 & 26056.0 \\
\hline PLOG /10 & $8.00 \mathrm{E} 13$ & 0 & 26056.0 \\
\hline PLOG /20 & $2.00 \mathrm{E}+14$ & 0 & 26056.0 \\
\hline PLOG /40 & $3.5 \mathrm{E}+14$ & 0 & 26056.0 \\
\hline PLOG /100 & $8.0 \mathrm{E}+14$ & 0 & 26056.0 \\
\hline
\end{tabular}

Page 4 of 16 
$\mathrm{C} 8 \mathrm{H} 16 \mathrm{OOH}+\mathrm{O}_{2}<=>\mathrm{C} 8 \mathrm{H} 16 \mathrm{OOH}-\mathrm{O} 2$

Reverse Arrhenius coefficient

$\mathrm{C} 8 \mathrm{H} 16 \mathrm{OOH}-\mathrm{O} 2<=>\mathrm{IC} 8 \mathrm{KET}+\mathrm{OH}$

$\mathrm{IC} 8 \mathrm{KET}=>\mathrm{CH}_{2} \mathrm{O}+\mathrm{CH}_{3}+\mathrm{OH}+\mathrm{C}_{4} \mathrm{H}_{8}+\mathrm{CH}_{2} \mathrm{CO}$

$\mathrm{C} 8 \mathrm{H} 16+\mathrm{O}_{2}=>\mathrm{IC}_{3} \mathrm{H}_{7}+\mathrm{CH}_{4}+\mathrm{C}_{2} \mathrm{H}_{2}+\mathrm{CH}_{2} \mathrm{O}+\mathrm{HCO}$

\begin{abstract}
$4.00 \mathrm{E}+14$
\end{abstract}
$7.14 \mathrm{E}+14$

$2.53 \mathrm{E}+12$

$1.00 \mathrm{E}+16$

$3.16 \mathrm{E}+13$
0

0.0

33900.0

26000.0

41600.0

10000.0

\subsection{Toluene sub-model}

Aromatic combustion chemistry is different from alkanes. Toluene doesn't exhibit low temperature combustion and starts to react at elevated temperatures, which highlights the importance of adding the different pyrolysis pathways in the reduced model. One of the major products in the toluene combustion chemistry is benzene, which required the addition of several reactions for the benzene consumption.

The same reactions included in the model by Liu et al. [38] were implemented, but rate parameters from the detailed toluene model by Mehl et al. [13] were adopted. 21 reactions and 8 species were included in the sub-model. Figure 1 presents a schematic diagram for the added pathways.

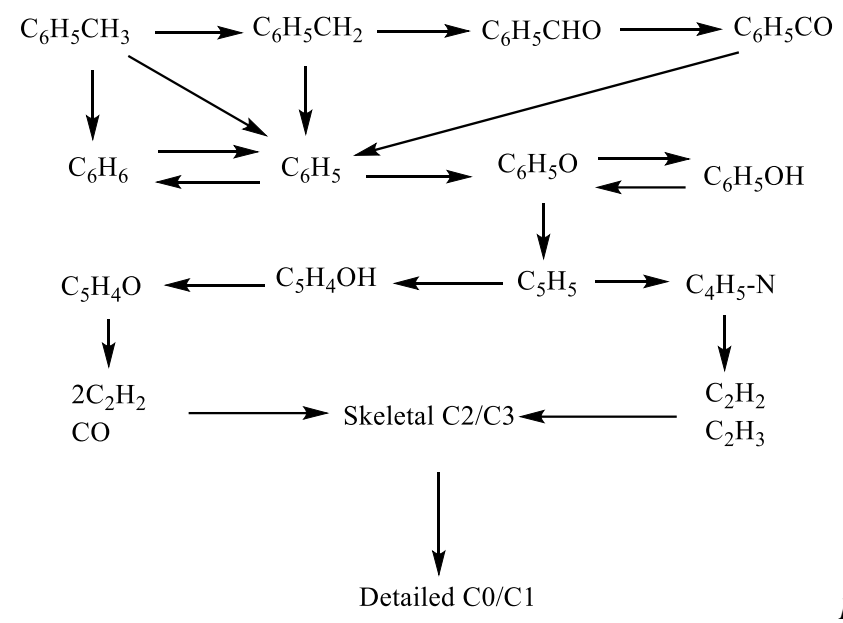

Figure 1 - Schematic diagram showing the pathways added for toluene combustion

\subsection{3-D CFD Model Description}

The reduced PRF mechanism was also validated through 3-D CFD engine simulations, simulating the combustion of a higher reactivity gasoline with a research octane number (RON) of 59 in a heavy-duty diesel engine. The commercial CFD software package, CONVERGE 2.3 [73], was used to conduct closed-cycle, sector mesh, combustion simulations. The model setup used in this study is the same as those in [74,75]. A detailed description of the primary CONVERGE sub-models can be found in Table 2. The base grid size was set at $1.4 \mathrm{~mm}$, while the smallest grid size was at $0.35 \mathrm{~mm}$ with the implementation of fixed nozzle embedding and adaptive mesh refinement (AMR) on velocity and temperature.

Table 3 - Primary CONVERGE v2.3 [73] sub-models

\begin{tabular}{|l|l|}
\hline Spray Models \\
\hline Injection & Blob \\
\hline Evaporation & Frossling \\
\hline Collision & NTC \\
\hline Break-up & KH-RT \\
\hline Combustion and Emissions \\
\hline Solver & SAGE \\
\hline $\begin{array}{l}\text { Fuel Liquid Physical } \\
\text { Properties }\end{array}$ & DHA \& Aspen HYSYS \\
\hline $\begin{array}{l}\text { Fuel Gas-Phase } \\
\text { Surrogate }\end{array}$ & PRF for RON59 gasoline \\
\hline $\begin{array}{l}\text { Chemical Kinetic } \\
\text { Mechanism }\end{array}$ & Reduced mechanism from this study \\
\hline
\end{tabular}

Page 5 of 16 


\begin{tabular}{|l|l|}
\hline NOx & 4 species and 13 reactions \\
\hline Soot & Hiroyasu-NSC \\
\hline Turbulence & RNG k-E \\
\hline Wall Heat Transfer & O'Rourke \& Amsden \\
\hline Grid Size & $1.4 \mathrm{~mm}$ \\
\hline Base & $0.35 \mathrm{~mm}$ \\
\hline Smallest
\end{tabular}

Combustion simulations were performed using a direct chemistry solver, SAGE, in CONVERGE. The reduced mechanism developed in this study was used to simulate the gas-phase chemistry of the RON59 gasoline. To capture the liquid physical properties of the RON59 gasoline, a physical surrogate was formulated based on the detailed hydrocarbon analysis (DHA) result. Temperature-dependent physical properties were then calculated in Aspen HYSYS using Peng-Robinson equation of state and several built-in property correlations. Aspen HYSYS is a chemical process simulation software. It performs wide range calculations involved in various chemical processes from small-scale unit operation to large-scale petroleum refineries. The current study uses its built-in physical property system to calculate the liquid properties of the gasoline physical surrogate [76]. Details on the gasoline physical surrogate formulation can be found in [77]. A PRF 59 mixture was used as the surrogate because the target fuel does not comprise significant aromatic fraction. The octane sensitivity of the fuel is very low, and previous studies have shown that PRF is a good autoignition surrogate at intermediate and high temperatures for low sensitivity fuels. A recently published a paper [78] on the ignition delay times of the RON 59 gasoline and its surrogates showed that PRF is a good autoignition surrogate at a wide range of conditions.

In terms of predicting engine-out emissions, a reduced NOx mechanism that contains 4 species and 13 reactions was used to capture the in-cylinder NOx emissions [31], while the two-step Hiroyasu-NSC (Nagle and Strickland-Constable) approach was used to predict the soot formation and oxidation process. In the soot model, acetylene was selected as the soot inception species.

\section{Results and Discussions}

The skeletal PRF mechanism developed here comprises 67 species and 354 chemical reactions. The addition of toluene for TPRF mixtures results in a skeletal model with 76 species and 401 reactions. The complete skeletal model including NOx chemistry is 80 species and 414 reactions. This compact chemical kinetic model is suitable for use in CFD simulations.

\subsection{Validation against fundamental combustion data}

The skeletal model was validated against a range of fundamental experimental data available in the literature. These includes premixed fuel/air laminar burning velocities and homogeneous gas-phase ignition delay times (IDT). Simulations were performed using the respective reactor modules in CHEMKIN PRO [79]. Ignition delay time was defined as the time between start of simulation to the point of maximum rate of change of temperature with time $(\max \mathrm{dT} / \mathrm{dt})$. The premixed laminar flame speed is defined as the propagation speed of the unstretched flame front balanced by convection, diffusion, and reaction. The proposed skeletal model is also compared against two widely used skeletal models from the literature, specifically that by Liu et al. [38] and by Wang et al. [41]. 

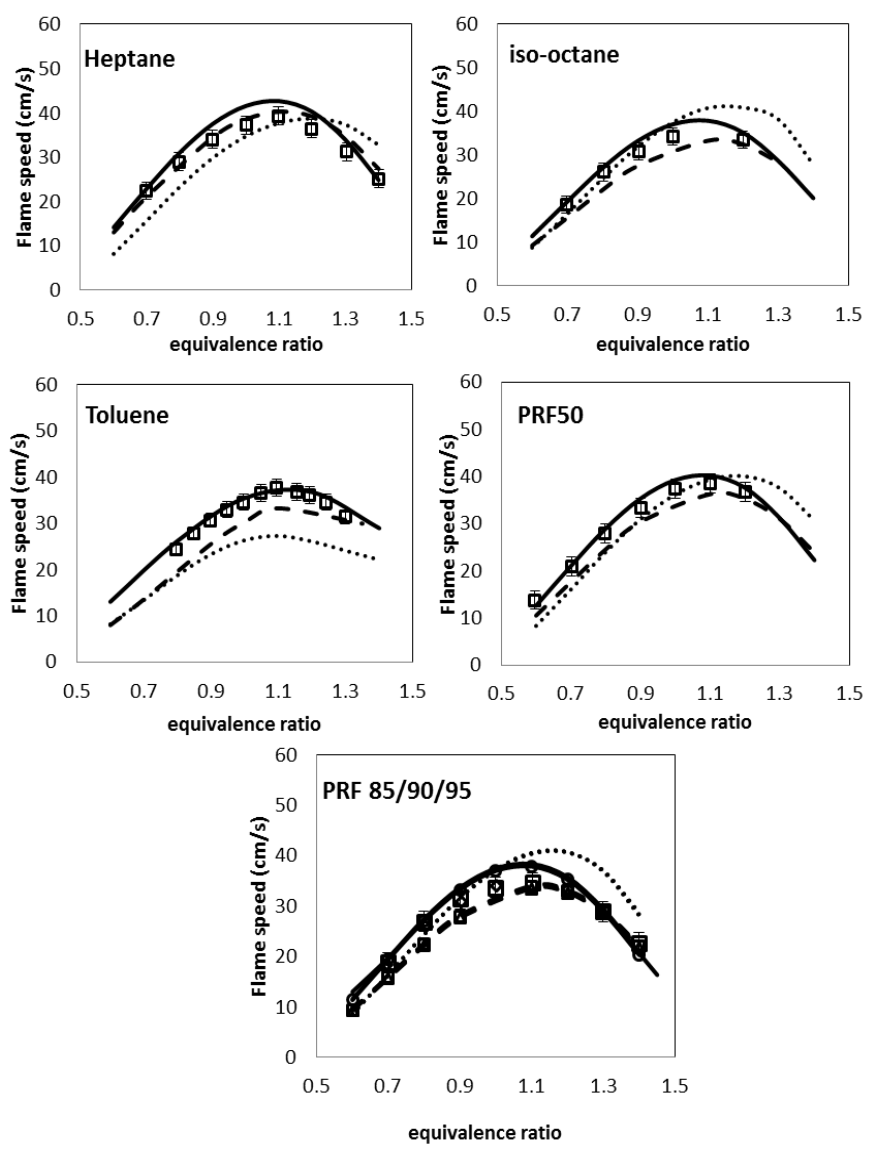

Figure 2 - Flame speed of pure components (n-heptane/iso-octane/toluene) and PRF mixtures at $1 \mathrm{~atm}$. and $298 \mathrm{~K}$. Symbols present experiments [80]. Solid, dashed and dotted lines present simulations using new model, Wang et al. [41] model and Liu et al. model [38], respectively.
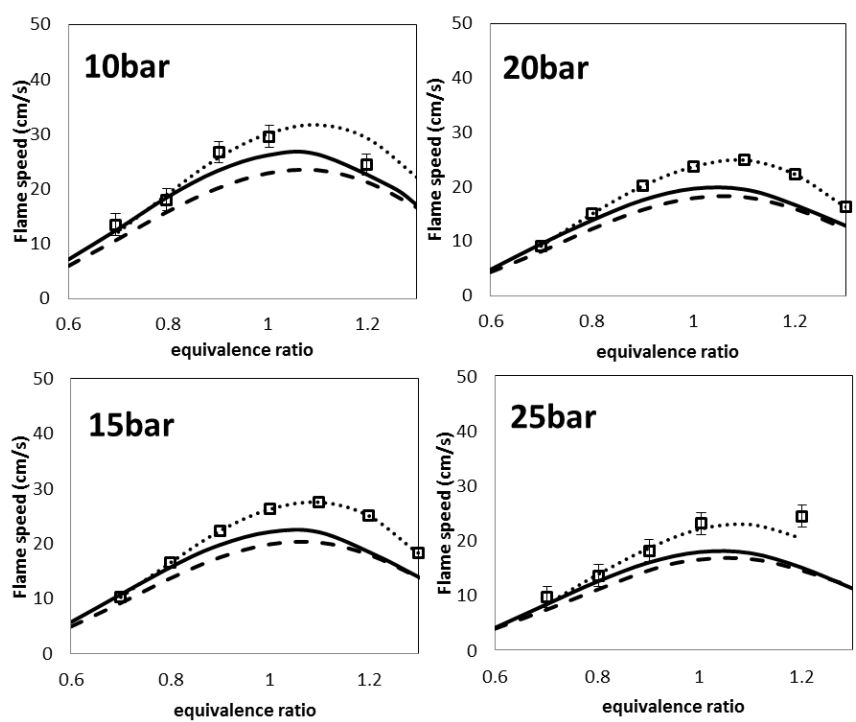
respectively.

Figures 2 and 3 compare the proposed skeletal model against laminar flame speeds for pure n-heptane, iso-octane, and toluene, as well as PRF mixtures. At atmospheric conditions (Fig 2) the new skeletal model accurately reproduces laminar flame speeds for all fuels at all equivalence ratios. The new model performs notably better than skeletal models available in the literature. The improvements in the new model can be attributed to the improved $\mathrm{C} 0-\mathrm{C} 4$ chemistry. The current skeletal model well predicted PRF 87 laminar flame speeds at 10 bar, but under predicts the data at high pressures (Fig 3). 


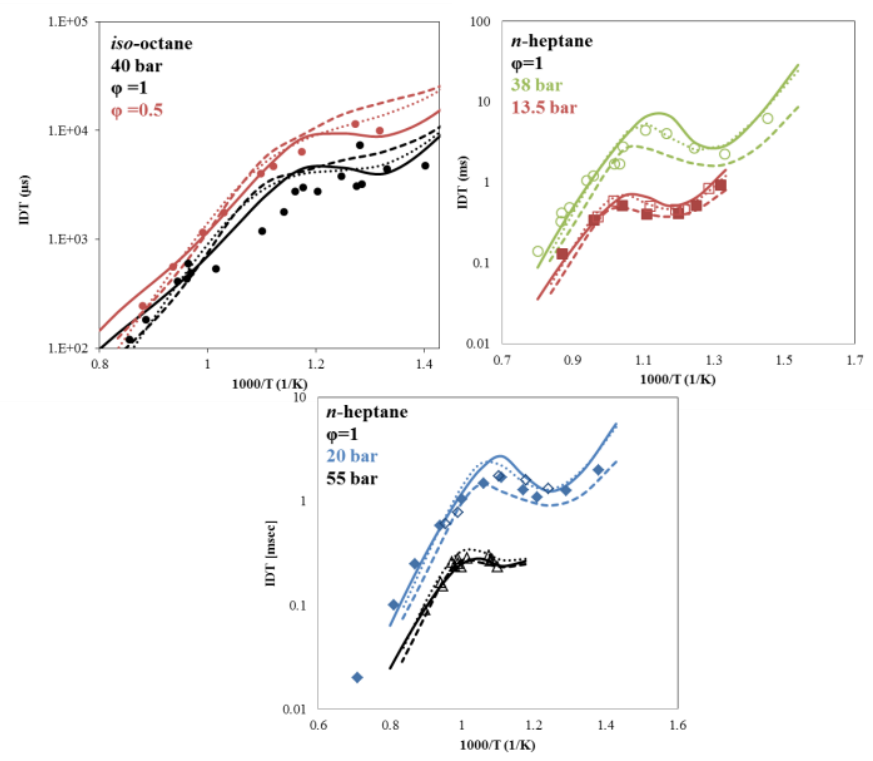

Figure 4 - IDT for pure iso-octane and n-heptane. iso-octane experiments are from [82], n-heptane experiments are from [17] (closed symbols) and [83] (open symbols). Solid, dashed and dotted lines present simulations using new model, Wang et al. [41] model and Liu et al. model [38], respectively.

Figure 4 compares the present skeletal model against experimental shock tube ignition delay data for iso-octane/air and n-heptane/air mixtures at various initial temperature, pressures and equivalence ratios. The proposed model accurately reproduces ignition delay times for these pure components in the low temperature, negative temperature coefficient (NTC), and high temperature regimes. In general, the proposed model performs better that literature skeletal models, albeit all the models perform fairly well.

IDT simulations for PRF/air mixtures are presented in Figure 5. The IDT of various PRF mixtures from PRF 60 to 95 were measure in a shock tube by [21]. Both lean and stoichiometric conditions were investigated at pressure from 10 to 40 bar and various temperatures. The simulation results show that all models behave similar at high temperature above $1000 \mathrm{~K}$ and are able to reproduce experimentally measure IDT for various PRFs at different initial conditions. However, the models differ notably in the intermediate temperature NTC and low temperature regimes. It is clear that models from the literature do not perform well for the lower octane PRFs (PRF 60, PRF 70 and PRF 80) in the NTC regime. The new skeletal model developed herein is able to better reproduce the experimental in the NTC regime. Given that the present study focuses on studying low octane gasoline fuels (e.g., RON 60-80), the new skeletal model is expected to better capture ignition regimes of these fuels in PPCI engine simulations. 

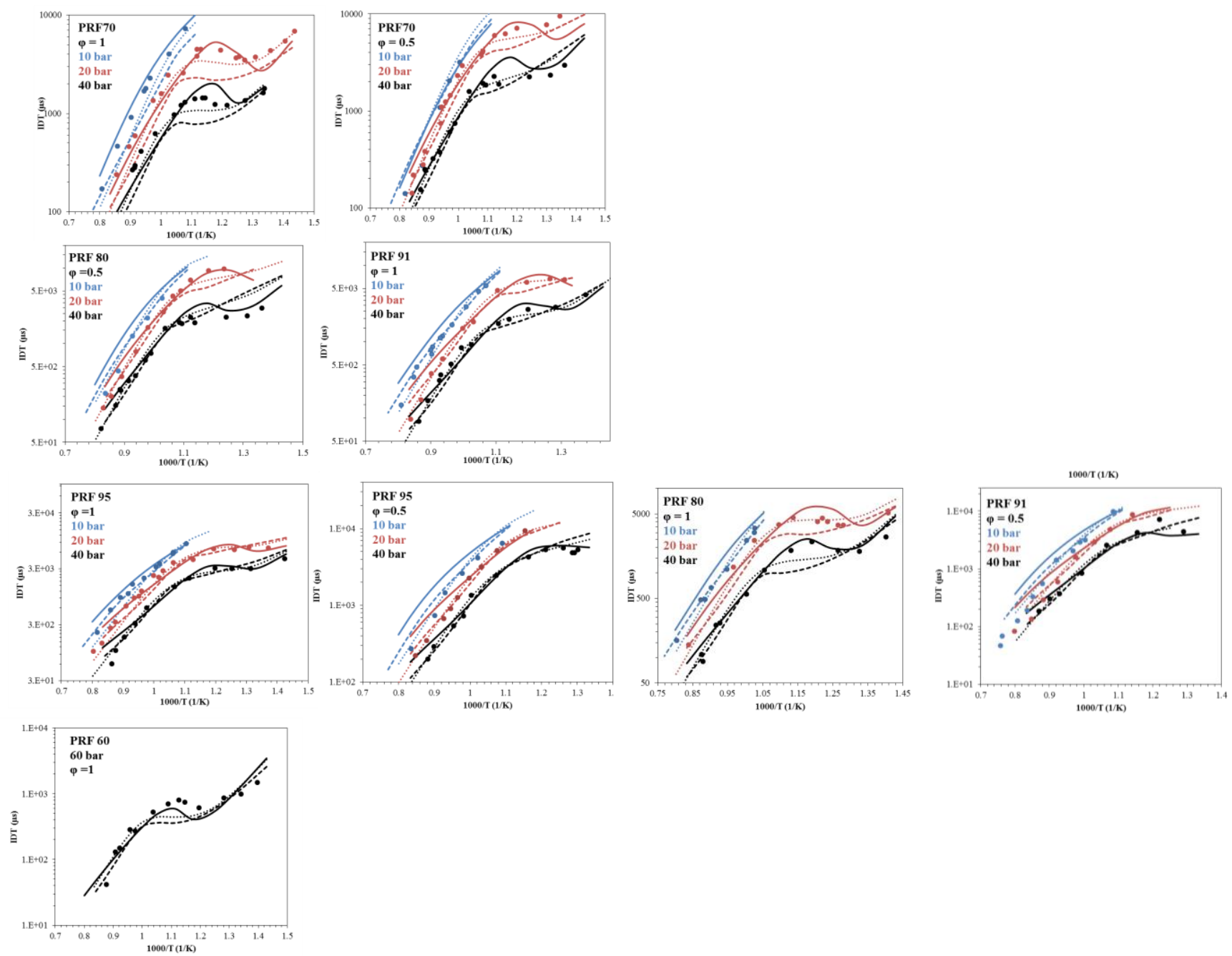

Figure 5 - IDT for different PRF mixtures at different pressures and equivalence ratios. Symbols present experimental data from [21]. Solid, dashed and dotted lines present simulations using new model, Wang et al. [41] model and Liu et al. model [38], respectively.

Figure 6 presents IDT simulations for TPRF/air mixtures across a range of pressures, temperatures, and equivalence ratios. The simulations are compared against shock tube experimental data from [22], and details of the TPRF mixture compositions are available in that study. In is evident that the dashed line simulations representing the Wang et al. [41] poorly predict the experimental data across most conditions. This model is thus not recommended for TPRF ignition simulations. The Liu et al. model [38] performs much better and is able to predict IDT measurements at most conditions; however, some discrepancies are observed in the NTC regime. The new skeletal model developed here better reproduces the experimental data, especially for lower octane TPRF mixture (i.e., TPRF 70 and TPRF 80). 

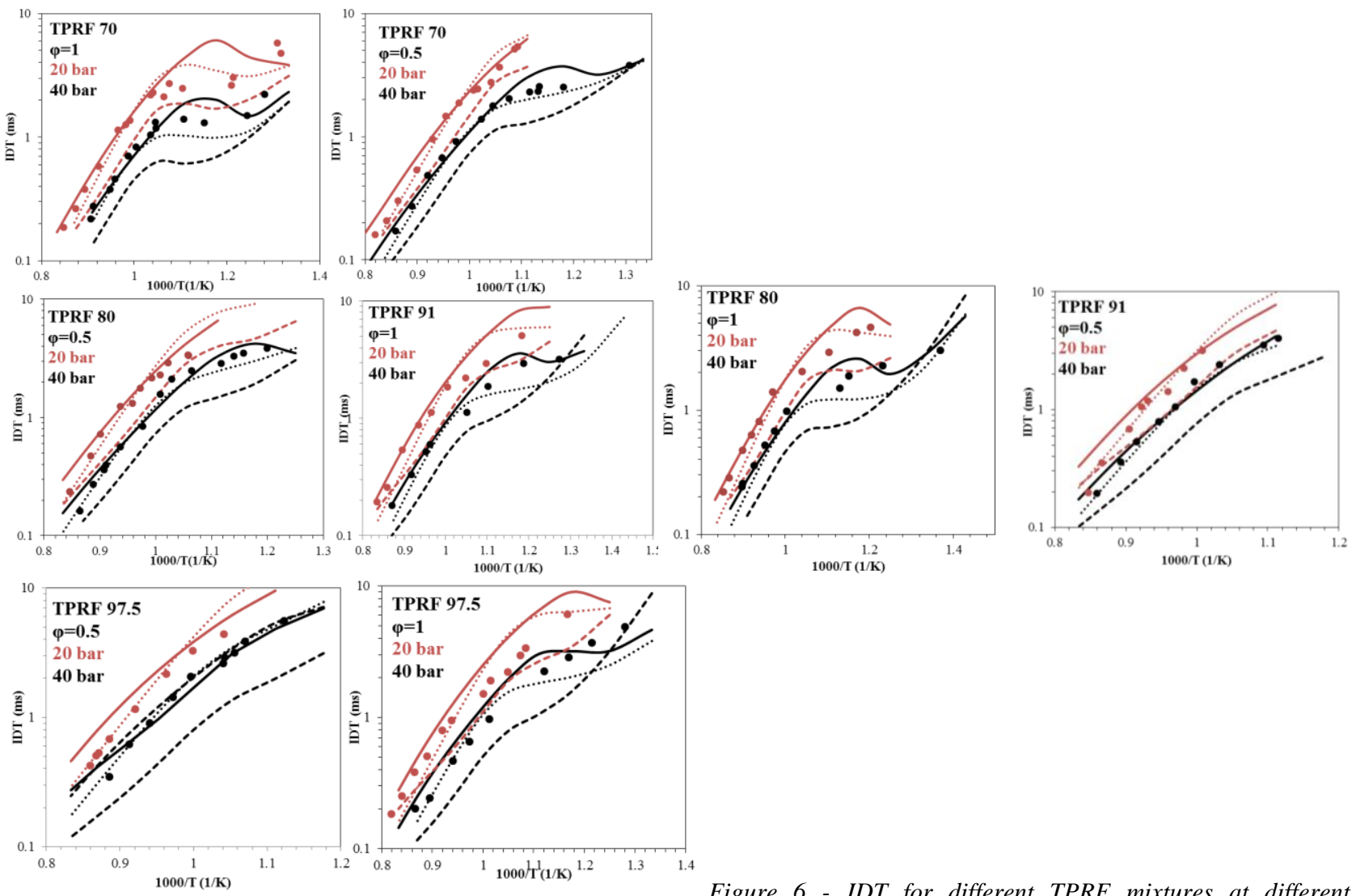

Figure 6 - IDT for different TPRF mixtures at different pressures and equivalence ratios. Symbols present experimental data from [22]. Solid, dashed and dotted lines present simulations using new model, Wang et al. [41] model and Liu et al. model [38], respectively.

\subsection{Validation in 3D CFD engine simulations}

The performance of the reduced mechanism was further examined by performing 3-D CFD, closed-cycle, sector mesh, engine combustion simulations to validate against the engine experimental data. The engine experimental data used in this study was from an investigation of the combustion and emissions characteristics of a RON59 gasoline in a model year (MY) 2013, Cummins ISX15 heavy-duty diesel engine [75]. Table 4 provides a list of the key properties for the RON59 gasoline. The key engine specifications can be found in Table 5. The simulations utilized PRF 59 as the surrogate fuel for kinetic modeling.

Table 4 - Properties of the RON59 gasoline

\begin{tabular}{|r|c|c|}
\hline & & $\begin{array}{c}\text { RON59 } \\
\text { Gasoline }\end{array}$ \\
\hline IBP & ${ }^{\circ} \mathrm{C}$ & 32 \\
\hline $\mathrm{T} 10$ & ${ }^{\circ} \mathrm{C}$ & 58 \\
\hline $\mathrm{T} 50$ & ${ }^{\circ} \mathrm{C}$ & 94 \\
\hline $\mathrm{T} 90$ & ${ }^{\circ} \mathrm{C}$ & 124 \\
\hline $\mathrm{FBP}$ & ${ }^{\circ} \mathrm{C}$ & 140 \\
\hline $\begin{array}{r}\text { Dry Vapor } \\
\text { Pressure }\end{array}$ & $\mathrm{psi}$ & 8.83 \\
\hline
\end{tabular}

Page 10 of 16 


\begin{tabular}{|c|c|c|}
\hline $\begin{array}{r}\text { Density at } 15.56 \\
{ }^{\circ} \mathrm{C}\end{array}$ & $\mathrm{g} / \mathrm{mL}$ & 0.705 \\
\hline $\begin{array}{r}\text { Kinematic } \\
\text { viscosity }\end{array}$ & $\mathrm{cSt}$ & 0.58 \\
\hline Aromatics & vol\% & 9.1 \\
\hline Olefins & vol\% & 0.4 \\
\hline Saturates & vol\% & 90.5 \\
\hline Sulfur & ppm & 19.3 \\
\hline $\mathrm{H} / \mathrm{C}$ ratio & $\mathrm{mol} / \mathrm{mol}$ & 2.124 \\
\hline $\begin{array}{r}\text { Cetane Number } \\
(\mathrm{CN})\end{array}$ & & 33.7 \\
\hline RON & - & 58.8 \\
\hline $\mathrm{MON}$ & - & 57.9 \\
\hline AKI & - & 58.4 \\
\hline $\begin{array}{r}\text { Lower heating } \\
\text { value }\end{array}$ & $\mathrm{MJ} / \mathrm{kg}$ & 43.363 \\
\hline
\end{tabular}

Table 5 - Engine Specifications

\begin{tabular}{|l|l|}
\hline Displacement Volume & $14.9 \mathrm{~L}$ \\
\hline Number of Cylinders & 6 \\
\hline Bore & $137 \mathrm{~mm}$ \\
\hline Stroke & $169 \mathrm{~mm}$ \\
\hline Compression Ratio & 18.9 \\
\hline Diesel Fuel System & 2500 bar common-rail \\
\hline Air System & $\begin{array}{l}\text { single-stage VGT pressure EGR loop with } \\
\text { cooling } \\
\text { charge air cooler }\end{array}$ \\
\hline
\end{tabular}

Page 11 of 16 


\begin{tabular}{|l|l|}
\hline Engine Ratings & $\begin{array}{l}336 \mathrm{~kW} @ 1800 \mathrm{rpm} \\
2375 \mathrm{~N}-\mathrm{m} @ 1000 \mathrm{rpm}\end{array}$ \\
\hline
\end{tabular}

Across the supplemental emission test (SET) 12-mode test, the RON59 gasoline demonstrated significantly lower soot compared to an ultra-low sulfur diesel while achieving the diesel-equivalent fuel efficiency and lower engine-out NOx emissions. Moreover, it was observed that despite the cetane number difference between the RON59 gasoline and the ULSD (33 vs. 44), both fuels exhibited similar ignition delay times at medium to high engine loads, suggesting the cylinder pressure and temperature at those engine operating conditions are sufficiently high to suppress the cetane number difference between the two fuels.

Therefore, when considering model validation, it is of interest to examine whether the reduced mechanism can accurately capture the ignition behavior of the RON59 gasoline at those medium-to-high load operating conditions. Consequently, the model validation was focused on 10 and 15 bar BMEP at 1375 rp. In addition, as seen in Table 4, the RON 59 gasoline has both low octane sensitivity and low aromatic content, making PRF a good surrogate candidate in terms of attaining a good balance between accuracy in prediction and computational cost when compared to a multicomponent surrogate.

The key engine operating boundary conditions can be found in Table 6. For the closed-cycle, sector mesh, combustion simulations performed in this study, the initial thermal conditions at intake valve closing (IVC) were acquired from a well-validated 1-D GT-Power model [84] for the engine. A single fuel injection strategy was used at both engine operating points. The injection rate shapes for the RON59 gasoline were derived based on the density difference between the RON59 gasoline and ULSD, while the injection rate shapes for ULSD were generated using a high fidelity hydraulic fuel injection system model for the Cummins XPI (Xtra-High Pressure Injection) common-rail fuel system.

The KH spray break-up model time constant and the spray plume angle of were tuned based on the spray experiments for the RON59 gasoline conducted in a constant-volume combustion chamber under the thermal environment and the fuel injection pressures similar to those encountered in this study [85]. The spray experiments covered an ambient pressure range of 30-100 bar and an ambient temperature range of 800-1200 K, while the fuel injection pressure for the RON59 gasoline was varied from 1000 to 2500 bar $[85,86]$. In addition, the soot pre-exponential factor was adjusted and kept the same at both engine operating points.

As seen in Figures 7 and 8, the onset of the combustion and the general heat release progression were captured reasonably well by the model. Note that the peak apparent heat release rate (AHRR) was under-predicted in both Figures 7 and 8, suggesting that there is room for further improvement on the surrogate fuel kinetics used or the high temperature chemistry of the reduced mechanism. In Figure 7, the model also predicted a slightly longer ignition delay, moderately enhanced premixed combustion, and a faster transition from premixed to mixing-controlled combustion. Therefore, the low-to-intermediate temperature chemistry can likely also be further refined by modifying the surrogate mixture to address these minor misalignments. Figure 9 shows that engine-out NOx and soot emissions were well aligned between the measured data and the model predictions at the two engine operating points examined in this study. Overall, the reduced mechanism demonstrated reasonably good fidelity in terms of predicating both the global combustion behavior and the engine-out NOx and soot emissions under the high pressure, mixing-controlled combustion conditions encountered in modern heavy-duty diesel engines.

Table 6 - Operating boundary conditions at 10 and 15 bar BMEP

\begin{tabular}{|r|c|c|}
\hline Engine Load & 10 bar BMEP & 15 bar BMEP \\
\hline SOI [ ${ }^{\circ}$ ATDC] & -9 & -6 \\
\hline $\begin{array}{r}\text { Inj. Pressure } \\
{[\mathrm{bar}]}\end{array}$ & 1450 & 1900 \\
\hline Pivc [bar] & 2.165 & 3.035 \\
\hline Tivc [K] & 385 & 405 \\
\hline $\mathrm{X}_{\mathrm{O} 2}[-]$ & 0.160 & 0.163 \\
\hline
\end{tabular}




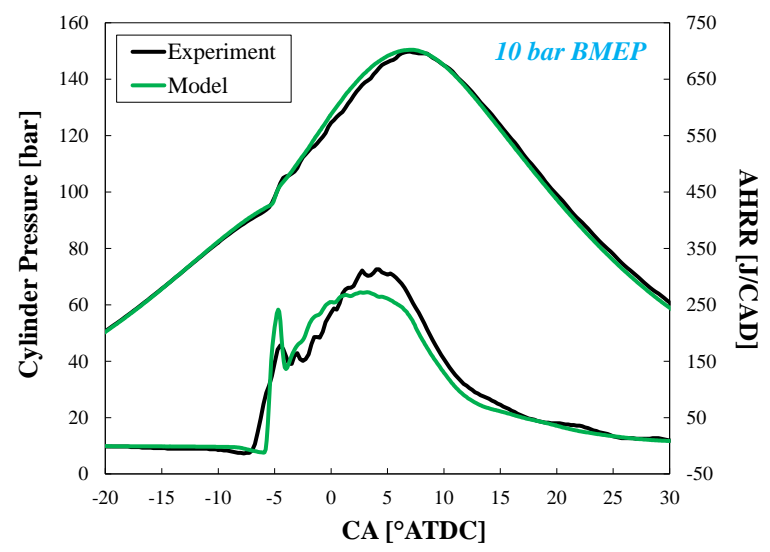

Figure 7 - Comparison of cylinder pressure and AHRR at 10 bar BMEP

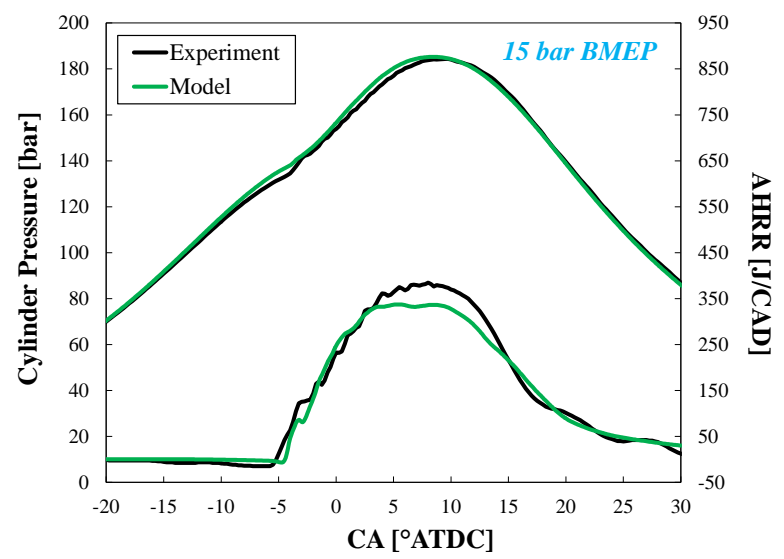

Figure 8 - Comparison of cylinder pressure and AHRR at 15 bar BMEP

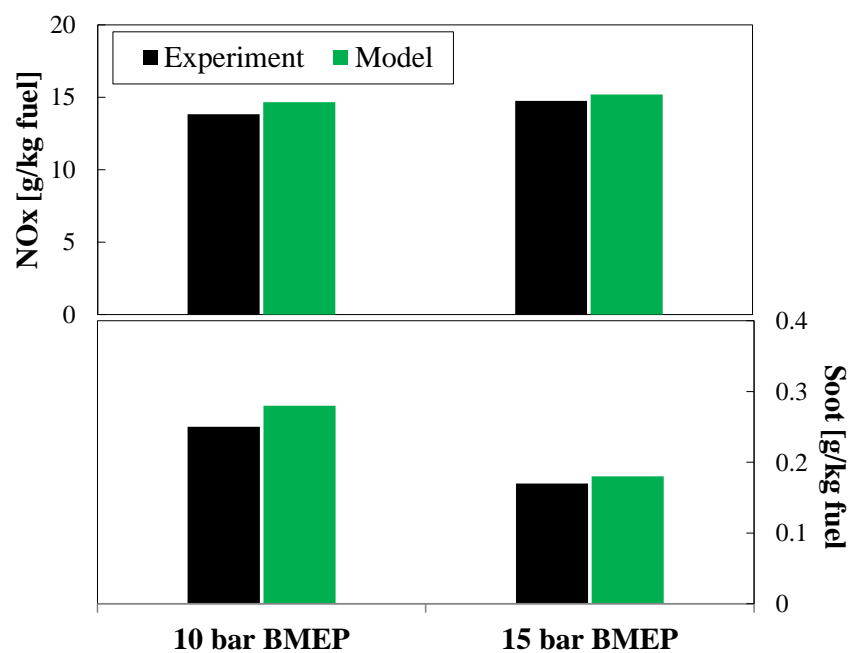

Figure 9 - Comparison of NOx and soot emissions at 10 and 15 bar BMEP

\section{Conclusions}

This work presented a comprehensively validated skeletal kinetic model for TPRF mixtures. The model was validated against laminar flame speed and ignition delay time measurements for pure components and mixtures across a range of temperature, pressure, and equivalence ratio conditions.

Page 13 of 16 
The proposed model showed reasonable level of agreement with the wide range of experimental data simulated. The skeletal mechanism was then utilized to simulate the combustion of a low octane gasoline fuel in a heavy duty compression ignition engine. The model was able to qualitatively predict both the premixed and mixing controlled combustion regimes observed experimentally, as well as soot and NOx emissions. Discrepancies observed between the CFD simulations and experiments may be attributed to the use of a simple PRF mixture as a surrogate for the real gasoline fuel. Future work will explore the use of a multicomponent surrogate chemical kinetic model to simulate the combustion properties of low octane gasolines in compression ignition engines.

\section{Acknowledgments}

KAUST and Saudi Aramco supported this work under the FUELCOM program.

\section{Contact}

Dr. S. Mani Sarathy

mani.sarathy@kaust.edu.sa

\section{References}

1. G.T. Kalghatgi, Developments in internal combustion engines and implications for combustion science andfuture transport fuels, 35 (2015) 101-115.

2. R.D. Reitz, Directions in internal combustion engine research, Combustion and Flame. 160 (2013) 1-8.

3. G.T. Kalghatgi, Fuel/Engine Interactions, Society of Automotive Engineers, 2014.

4. A. Ahmed, G. Goteng, V.S.B. Shankar, K. Al-Qurashi, W.L. Roberts, S.M. Sarathy, A computational methodology for formulating gasoline surrogate fuels with accurate physical and chemical kinetic properties, Fuel. 143 (2015) 290-300.

5. S.M. Sarathy, G. Kukkadapu, M. Mehl, T. Javed, A. Ahmed, N. Naser, et al., Compositional effects on the ignition of FACE gasolines, Combustion and Flame. 169 (2016) 171-193.

6. N. Naser, M. Jaasim, N. Atef, S.H. Chung, H.G. Im, S.M. Sarathy, On the effects of fuel properties and injection timing in partially premixed compression ignition of low octane fuels, Fuel. 207 (2017) 373-388.

7. J.C.G. Andrae, P. Björnbom, R.F. Cracknell, G.T. Kalghatgi, Autoignition of toluene reference fuels at high pressures modeled with detailed chemical kinetics, Combustion and Flame. 149 (2007) 2-24.

8. J.C.G. Andrae, D. Johansson, P. Björnbom, P. Risberg, G. Kalghatgi, Co-oxidation in the auto-ignition of primary reference fuels and nheptane/toluene blends, Combustion and Flame. 140 (2005) 267-286.

9. J.C.G. Andrae, Comprehensive chemical kinetic modeling of toluene reference fuels oxidation, Fuel. 107 (2013) $740-748$.

10. M. Mehl, J.-Y. Chen, W.J. Pitz, S.M. Sarathy, C.K. Westbrook, An approach for formulating surrogates for gasoline with application toward a reduced surrogate mechanism for CFD engine modeling, Energ Fuel. 25 (2011) 5215-5223.

11. H. Curran, P. Gaffuri, W. Pitz, C. Westbrook, A comprehensive modeling study of n-heptane oxidation, Combustion and Flame. 114 (1998) 149-177.

12. H. Curran, P. Gaffuri, W. Pitz, C. Westbrook, A comprehensive modeling study of iso-octane oxidation, Combustion and Flame. 129 (2002) 253-280.

13. M. Mehl, W.J. Pitz, C.K. Westbrook, H.J. Curran, Kinetic modeling of gasoline surrogate components and mixtures under engine conditions, Proceedings of the Combustion Institute. 33 (2011) 193-200.

14. S.M. Burke, W. Metcalfe, O. Herbinet, F. Battin-Leclerc, F.M. Haas, J. Santner, et al., An experimental and modeling study of propene oxidation. Part 1: Speciation measurements in jet-stirred and flow reactors, Combustion and Flame. 161 (2014) $2765-2784$.

15. S.M. Burke, U. Burke, R. Mc Donagh, O. Mathieu, I. Osorio, C. Keesee, et al., An experimental and modeling study of propene oxidation. Part 2: Ignition delay time and flame speed measurements, Combustion and Flame. 162 (2015) 296-314.

16. W.K. Metcalfe, S.M. Burke, S.S. Ahmed, H.J. Curran, A Hierarchical and Comparative Kinetic Modeling Study of C1-C2 Hydrocarbon and Oxygenated Fuels, International Journal of Chemical Kinetics. 45 (2013) 638-675.

17. K. Zhang, C. Banyon, J. Bugler, H.J. Curran, A. Rodriguez, O. Herbinet, et al., An updated experimental and kinetic modeling study of nheptane oxidation, Combustion and Flame. 172 (2016) 116-135.

18. N. Atef, G. Kukkadapu, S.Y. Mohamed, M. Al Rashidi, C. Banyon, M. Mehl, et al., A comprehensive iso-octane combustion model with improved thermochemistry and chemical kinetics, Combustion and Flame. 178 (2017) 111-134.

19. W.K. Metcalfe, S. Dooley, F.L. Dryer, Comprehensive Detailed Chemical Kinetic Modeling Study of Toluene Oxidation, Energy Fuels. (2011) 111006141758009

20. Y. Zhang, K.P. Somers, M. Mehl, W.J. Pitz, R.F. Cracknell, H.J. Curran, Probing the antagonistic effect of toluene as a component in surrogate fuel models at low temperatures and high pressures. A case study of toluene/dimethyl ether mixtures, Proceedings of the Combustion Institute. 36 (2017) 413-421.

21. M. AlAbbad, T. Javed, F. Khaled, J. badra, A. Farooq, Ignition delay time measurements of primary reference fuel blends, Combustion and Flame. 178 (2017) 205-216.

22. T. Javed, C. Lee, M. AlAbbad, K. Djebbi, M. Beshir, J. badra, et al., Ignition studies of n-heptane/iso-octane/toluene blends, Combustion and Flame. 171 (2016) 223-233.

23. S. Tanaka, F. Ayala, J.C. Keck, A reduced chemical kinetic model for HCCI combustion of primary reference fuels in a rapid compression machine, Combustion and Flame. 133 (2003) 467-481.

24. M. Chaos, A. Kazakov, Z. Zhao, F.L. Dryer, A high-temperature chemical kinetic model for primary reference fuels, International Journal of Chemical Kinetics. 39 (2007) 399-414.

25. H. Wang, M. Yao, R.D. Reitz, Development of a Reduced Primary Reference Fuel Mechanism for Internal Combustion Engine Combustion Simulations, Energ Fuel. 27 (2013) 7843-7853.

26. M.B. Luong, Z. Luo, T. Lu, S.H. Chung, C.S. Yoo, Direct numerical simulations of the ignition of lean primary reference fuel/air mixtures with temperature inhomogeneities, Combustion and Flame. (2013) 1-10.

Page 14 of 16 
27. Y. Ra, R. Reitz, A reduced chemical kinetic model for IC engine combustion simulations with primary reference fuels, Combustion and Flame. 155 (2008) 713-738.

28. X. Zhen, Y. Wang, D. Liu, Energy Conversion and Management, Energy Conversion and Management. 109 (2016) $113-121$.

29. Z. Wang, F. Li, Y. Wang, A generalized kinetic model with variable octane number for engine knock prediction, Fuel. 188 (2017) 489499.

30. D. Zhou, W. Yang, H. An, J. Li, M. Kraft, An Enhanced Primary Reference Fuel Mechanism Considering Conventional Fuel Chemistry in Engine Simulation, Journal of Engineering for Gas Turbines and Power. 138 (2016) 092804-8.

31. Y.-D. Liu, M. Jia, M.-Z. Xie, Bin Pang, Enhancement on a Skeletal Kinetic Model for Primary Reference Fuel Oxidation by Using a Semidecoupling Methodology, Energ Fuel. 26 (2012) 7069-7083.

32. H. Machrafi, S. Cavadias, P. Gilbert, An experimental and numerical analysis of the HCCI auto-ignition process of primary reference fuels, toluene reference fuels and diesel fuel in an engine, varying the engine parameters, Fuel Processing Technology. 89 (2008) $1007-1016$.

33. H. Machrafi, S. Cavadias, J. Amouroux, The development and experimental validation of a reduced ternary kinetic mechanism for the autoignition at HCCI conditions, proposing a global reaction path for ternary gasoline surrogates, Fuel Processing Technology. 90 (2009) 247263.

34. H. Machrafi, S. Cavadias, P. Guibert, An experimental and numerical investigation on the influence of external gas recirculation on the HCCI autoignition process in an engine: Thermal, diluting, and chemical effects, Combustion and Flame. 155 (2008) $476-489$.

35. Y. Kim, K. Min, M.S. Kim, S.H. Chung, C. Bae, Development of a Reduced Chemical Kinetic Mechanism and Ignition Delay Measurement in a Rapid Compression Machine for CAI Combustion, SAE Technical Paper Series. 1 (2007) 2007-01-0218.

36. K. Lee, Y. Kim, K. Min, Development of a reduced chemical kinetic mechanism for a gasoline surrogate for gasoline HCCI combustion, Combustion Theory and Modelling. 15 (2010) 107-124.

37. A. Raj, I.D.C. Prada, A.A. Amer, S.H. Chung, A reaction mechanism for gasoline surrogate fuels for large polycyclic aromatic hydrocarbons, Combustion and Flame. (2011) 1-16.

38. Y.-D. Liu, M. Jia, M.-Z. Xie, B. Pang, Development of a New Skeletal Chemical Kinetic Model of Toluene Reference Fuel with Application to Gasoline Surrogate Fuels for Computational Fluid Dynamics Engine Simulation, Energy Fuels. 27 (2013) $4899-4909$.

39. J.C.G. Andrae, Kinetic Modeling of the Influence of NO on the Combustion Phasing of Gasoline Surrogate Fuels in an HCCI Engine, Energ Fuel. 27 (2013) 7098-7107.

40. J.C.G. Andrae, Semidetailed Kinetic Model for Gasoline Surrogate Fuel Interactions with the Ignition Enhancer 2-Ethylhexyl Nitrate, Energ Fuel. 29 (2015) 3944-3952.

41. H. Wang, M. Yao, Z. Yue, M. Jia, R.D. Reitz, A reduced toluene reference fuel chemical kinetic mechanism for combustion and polycyclic-aromatic hydrocarbon predictions, Combustion and Flame. 162 (2015) 2390-2404.

42. Z. Zheng, Z. Lv, A new skeletal chemical kinetic model of gasoline surrogate fuel with nitric oxide in HCCI combustion, Applied Energy. 147 (2015) 59-66.

43. A. Stagni, A. Frassoldati, A. Cuoci, T. Faravelli, E. Ranzi, Skeletal mechanism reduction through species-targeted sensitivity analysis, Combustion and Flame. 163 (2016) 382-393

44. Y.-Z. An, Y.-Q. Pei, J. Qin, H. Zhao, X. Li, Kinetic modeling of polycyclic aromatic hydrocarbons formation process for gasoline surrogate fuels, Energy Conversion and Management. 100 (2015) 249-261.

45. Y.-Z. An, Y.-Q. Pei, J. Qin, H. Zhao, S.-P. Teng, B. Li, et al., Development of a PAH (polycyclic aromatic hydrocarbon) formation model for gasoline surrogates and its application for GDI (gasoline direct injection) engine CFD, Energy. 94 (2016) 367-379.

46. C.P. Kolodziej, M. Sellnau, K. Cho, D. Cleary, Operation of a Gasoline Direct Injection Compression Ignition Engine on Naphtha and E10 Gasoline Fuels, SAE Int. J. Engines. 9 (2016) 2016-01-0759-23.

47. J.A. Badra, J. Sim, A. Elwardany, M. Jaasim, Y. Viollet, J. Chang, et al., Numerical Simulations of Hollow-Cone Injection and Gasoline Compression Ignition Combustion With Naphtha Fuels, J. Energy Resour. Technol. 138 (2016) 052202.

48. J. Badra, Y. Viollet, A. Elwardany, H.G. Im, J. Chang, Physical and chemical effects of low octane gasoline fuels on compression ignition combustion, Applied Energy. 183 (2016) 1-12.

49. J. Chang, Y. Viollet, A. Amer, G. Kalghatgi, Fuel Economy Potential of Partially Premixed Compression Ignition (PPCI) Combustion with Naphtha Fuel, SAE International, Warrendale, PA, 2013/

50. J. Chang, G. Kalghatgi, A. Amer, Y. Viollet, Enabling High Efficiency Direct Injection Engine with Naphtha Fuel through Partially Premixed Charge Compression Ignition Combustion, SAE International, Warrendale, PA, 2012.

51. A.K. Agarwal, A.P. Singh, R.K. Maurya, Evolution, challenges and path forward for low temperature combustion engines, Progress in Energy and Combustion Science. 61 (2017) 1-56.

52. R.F. Cracknell, D.J. Rickeard, J. Ariztegui, K.D. Rose, M. Muether, M. Lamping, et al., Advanced Combustion for Low Emissions and High Efficiency Part 2: Impact of Fuel Properties on HCCI Combustion, in: SAE Technical Paper Series, SAE International, 400 Commonwealth Drive, Warrendale, PA, United States, 2008: pp. 2008-01-2404.

53. P.C. Bakker, J.E. De Abreu Goes, L.M.T. Somers, B.H. Johansson, Characterization of Low Load PPC Operation using RON70 Fuels, in: Sae, SAE International, 400 Commonwealth Drive, Warrendale, PA, United States, 2014: pp. 2014-01-1304-13.

54. L. Hildingsson, B. Johansson, G.T. Kalghatgi, Some effects of fuel autoignition quality and volatility in premixed compression ignition engines, SAE Int. J. Engines. 3 (2010) 440-460.

55. S.M. Sarathy, G. Kukkadapu, M. Mehl, W. Wang, S.M. Sarathy, G. Kukkadapu, et al., Ignition of alkane-rich FACE gasoline fuels and their surrogate mixtures, in: 2015: pp. 249-257.

56. G. Kukkadapu, K. Kumar, C.-J. Sung, M. Mehl, W.J. Pitz, Autoignition of gasoline and its surrogates in a rapid compression machine, Proceedings of the Combustion Institute. 34 (2013) 345-352.

57. G. Kukkadapu, K. Kumar, C.-J. Sung, M. Mehl, W.J. Pitz, Autoignition of gasoline surrogates at low temperature combustion conditions, Combustion and Flame. 162 (2015) 2272-2285.

58. G. Kukkadapu, K. Kumar, C.-J. Sung, M. Mehl, W.J. Pitz, Experimental and surrogate modeling study of gasoline ignition in a rapid compression machine, Combustion and Flame. (2012).

59. V. Shankar, M. Sajid, K. Al-Qurashi, N. Atef, I. Alkhesho, Primary Reference Fuels (PRFs) as Surrogates for Low Sensitivity Gasoline Fuels, (2016).

Page 15 of 16 
60. A. Ahmed, M. Waqas, N. Naser, E. Singh, W. Roberts, S. Chung, et al., Compositional Effects of Gasoline Fuels on Combustion, Performance and Emissions in Engine, SAE Int. J. Fuels Lubr. 9 (2016) 1-9.

61. C. Bingjie, C. Togbe, W. Zhandong, P. Dagaut, S.M. Sarathy, Jet-stirred reactor oxidation of alkane-rich FACE gasoline fuels, Proceedings of the Combustion Institute. (2016) 1-8.

62. B. Chen, C. Togbe, H. Selim, P. Dagaut, S.M. Sarathy, Quantities of Interest in Jet Stirred Reactor Oxidation of a High-Octane Gasoline, Energ Fuel. (2017) acs.energyfuels.6b03193-11. doi:10.1021/acs.energyfuels.6b03193.

63. T. Javed, A. Ahmed, L. Lovisotto, G. Issayev, J. badra, S.M. Sarathy, et al., Ignition studies of two low-octane FACE gasolines, Combustion and Flame. (n.d.).

64. H. Hao, F. Liu, Z. Liu, F. Zhao, Compression ignition of low-octane gasoline: Life cycle energy consumption and greenhouse gas emissions, Applied Energy. 181 (2016) 391-398.

65. Y. Chang, M. Jia, Y. Li, Y. Liu, M. Xie, H. Wang, et al., Development of a skeletal mechanism for diesel surrogate fuel by using a decoupling methodology, Combustion and Flame. 162 (2015) 3785-3802.

66. Y. Chang, M. Jia, Y. Liu, Y. Li, M. Xie, Development of a new skeletal mechanism for n-decane oxidation under engine-relevant conditions based on a decoupling methodology, Combustion and Flame. (2013) 1-18.

67. T. Lu, C. Law, A directed relation graph method for mechanism reduction, 30 (2005) 1333-1341.

68. T. Lu, M. Plomer, Z. Luo, S.M. Sarathy, W.J. Pitz, S. Som, et al., Directed Relation Graph with Expert Knowledge for Skeletal Mechanism Reduction, 2011 7th US National Combustion Meeting. (2011) 1-10.

69. A. Alfazazi, U. Niemann, H. Selim, R.J. Cattolica, S.M. Sarathy, Effects of Substitution on Counterflow Ignition and Extinction of C3 and C4 Alcohols, Energ Fuel. 30 (2016) 6091-6097.

70. L. Yang, Z. Chong-Wen, H.J. Curran, An extensive experimental and modeling study of 1-butene oxidation, Combustion and Flame. 181 (2017) 198-213.

71. C.-W. Zhou, Y. Li, E. O'Connor, K.P. Somers, S.B. Thion, C. Keesee, et al., Combustion and Flame, Combustion and .... (2016) 1-27.

72. T. Tsurushima, A new skeletal PRF kinetic model for HCCI combustion, 32 (2009) 2835-2841.

73. Richards, K., Senecal, P., Pomraning, E., "CONVERGE 2.3 Theory Manual". Convergent Science Inc., Madison, WI.

74. Y. Zhang, S. Sommers, Y. Pei, P. Kumar, A. Voice, M. Traver, et al., Mixing-Controlled Combustion of Conventional and Higher Reactivity Gasolines in a Multi-Cylinder Heavy-Duty Compression Ignition Engine, in: Sae, SAE International, 400 Commonwealth Drive, Warrendale, PA, United States, 2017: pp. 2017-01-0696-22.

75. Zhang, Y, Voice, A., Tzanetakis, T., Traver, M., et al., “An Evaluation of Combustion and Emissions Performance with Low Cetane Naphtha Fuels in a Multi-Cylinder Heavy-Duty Diesel Engine,” J. Eng. Gas Turbines Power, 138(10):102805(1-10), 2016.

76. Aspen HYSYS v8.6. Help file - Appendix A: Property Methods and Calculations.

77. Zhang, Y., Voice, A., Pei, Y., Traver, M., and Cleary, D., "A Computational Investigation of Fuel Chemical and Physical Properties Effects on Gasoline Compression Ignition in a Heavy-Duty Diesel Engine," Paper No. ICEF2017-3664, ASME 2017 Internal Combustion Engine Division Conference, Seattle, WA, USA, October 15-18, 2017.

78. AlAbbad, M., Issayev, G., Badra, J., Voice, A.K., Giri, B.R., Djebbi, K., Ahmed, A., Sarathy, S.M., Farooq, A., “Autoignition of StraightRun Naphtha: A Promising Fuel for Advanced Compression Ignition Engines”, Combust. Flame. 189 (2018) 337-346.

79. CHEMKIN-PRO 15112, Reaction design, San Diego, 2011.

80. Y. Huang, C. Sung, J. Eng, Laminar flame speeds of primary reference fuels and reformer gas mixtures, Combustion and Flame. 139 (2004) 239-251.

81. S. Jerzembeck, N. Peters, P. Pepiot-Desjardins, H. Pitsch, Laminar burning velocities at high pressure for primary reference fuels and gasoline: Experimental and numerical investigation, Combustion and Flame. 156 (2009) 292-301.

82. M. Hartmann, I. Gushterova, M. Fikri, C. Schulz, R. Schieß1, U. Maas, Auto-ignition of toluene-doped n-heptane and iso-octane/air mixtures: High-pressure shock-tube experiments and kinetics modeling, Combustion and Flame. 158 (2011) 172-178.

83. H. Ciezki, G. Adomeit, Shock-tube investigation of self-ignition of n-heptane-air mixtures under engine relevant conditions, Combustion and Flame. 93 (1993) 421-433.

84. Gamma Software, GT-Power Engine Simulation Software. https://www.gtisoft.com/gt-suite-applications/propulsion-systems/gt-powerengine-simulation-software/

85. Pei, Y., Torelli, R., Tzanetakis, T., Zhang, Y., Traver, M., Cleary, D., and Som, S., "Modeling the Fuel Spray of a High reactivity Gasoline under Heavy-Duty Diesel Engine Conditions," Paper No. ICEF2017-3530, ASME 2017 Internal Combustion Engine Division Conference, Seattle, WA, USA, October 15-18 (2017).

86. Meng, T., Pei, Y., Zhang, Y., Tzanetakis, T., Traver, M., Cleary, D., Quan, S., Naber, J., Lee, S., "Development of a Transient Spray Cone Angle Correlation for CFD Simulations at Diesel Engine Conditions," 18PFL-0673, submitted to SAE 2018 World Congress. 